\title{
Laser-triggered combined chemotherapy and photodynamic therapy enabled by iron sulfide- doxorubicin@bovine lactoferrin nanozymes for breast cancer therapy
}

\author{
Shipeng Ning \\ Guangxi Medical University \\ Yang Zheng \\ Guangxi Medical University \\ Kun Qiao \\ Harbin Medical University \\ Guozheng Li \\ Harbin Medical University \\ Shouping Xu \\ Harbin Medical University
}

Qian Bai ( $\sim$ qianbai.zhehospital@yahoo.com )

Zhengzhou University

\section{Research Article}

Keywords: Breast cancer, Gas therapy, Chemotherapy, Nanozyme, Fenton reaction

Posted Date: June 15th, 2021

DOI: https://doi.org/10.21203/rs.3.rs-332523/v2

License: (c) (i) This work is licensed under a Creative Commons Attribution 4.0 International License.

Read Full License 


\section{Abstract}

\section{Background}

The use of magnetic nanozymes with the ability to synchronize gas therapy through photodynamic and chemotherapy in the treatment of breast cancer has received much attention.

\section{Results}

Hence, in this study, we designed a bovine lactoferrin-coated iron sulfide nanozymes containing doxorubicin (FeS-Dox@bLf NZs) by wet chemical synthesis that can respond to tumor acidity. Then, the physicochemical properties of synthesized NZs were investigated by TEM, SEM, DLS and spectroscopic methods. Likewise, the level of $\mathrm{Fe}^{2+}$ release, $\mathrm{H}_{2} \mathrm{~S}$ and Dox from FeS-Dox@Lf NZs under acidic conditions was evaluated. It was observed that $\mathrm{Fe}^{2+}$ and $\mathrm{S}^{2-}$ caused significant $\mathrm{OH}$ and $\mathrm{H}_{2} \mathrm{~S}$ release through the Fenton reaction. Also, the toxic effects of FeS-Dox@Lf NZs on 4T1 cancerous cells were investigated by MTT and flow cytometry assays. After intravenous injections of NZs and laser irradiation, significant effects of FeS-Dox@Lf NZs on mice weight and tumor status were observed. Afterwards, not only the distribution of Dox in the body was examined by fluorescent, but also the time of Fe clearance and the amount of Dox and Fe retention in vital tissues were determined. The findings confirm that FeS-Dox@Lf $\mathrm{NZs}$, in addition to targeted drug distribution in tumor tissue, resulted in superior therapeutic performance compared to free Dox due to reduced Dox side effects in vital tissues, and increased level of free radicals in $4 \mathrm{~T} 1$ cells.

\section{Conclusion}

Overall, FeS-Dox@Lf nanozymes with the ability to synchronize chemotherapy and gas therapy raised hopes for more effective treatment of breast cancer.

\section{Introduction}

Breast cancer is one of the most challenging diseases in women that the use of new techniques based on nanoplatforms with less invasiveness has increased the hopes of treatment [1, 2]. In this regard, the use of magnetic nanoparticles (NPs) with enzyme-like behaviors for producing radicals $[3,4]$ along with the provision of imaging [5], photothermal therapy (PTT) [6], photodynamic therapy (PDT) [7] and chemotherapy [8] have received much attention. The enzymatic-like activity of magnetic NPs induces apoptosis by persuading radicals in cancerous cells through damage of fat, protein and DNA $[9,10]$. For this purpose, several papers have been published based on iron nanozymes (Fe NZs) that show the formation of radicals through the Fenton reaction on hydrogen peroxide $\left(\mathrm{H}_{2} \mathrm{O}_{2}\right)$ inside and outside of cells [11-13]. However, the results demonstrate that the amount of $\mathrm{H}_{2} \mathrm{O}_{2}$ in cancerous cells, especially breast cancer, is not high enough to generate reactive oxygen species (ROS) by Fe NZs $[4,14,15]$. On the other hand, several results exhibit that cancerous cells use enzymatic and non-enzymatic antioxidant Loading [MathJax]/jax/output/CommonHTML/jax.js id accumulation of radicals $[16,17]$. Therefore, development 
of free radicals-based therapeutic platforms to control breast cancer cells have received a great deal of interest, recently.

Gas therapy through hydrogen, nitric oxide $(\mathrm{NO})$ and hydrogen sulfide $\left(\mathrm{H}_{2} \mathrm{~S}\right)$ are modern and effective methods in medical activities for antibacterial [18], cardiovascular [19], neurological [20], antiinflammatory [21] and anti-cancer activities [22, 23]. Conventionally, $\mathrm{H}_{2} \mathrm{~S}$ and $\mathrm{NO}$ gases have been reported in the human body, especially in the mitochondria, which can enhance their use in medical practice [24]. The reports reveal that $\mathrm{H}_{2} \mathrm{~S}$ kills breast cancer cells by stopping the cell cycle through damage to mitochondria and miRNA $[25,26]$. On the other hand, $\mathrm{H}_{2} \mathrm{~S}$ inhibits catalase activity dramatically [27]. Because, $\mathrm{H}_{2} \mathrm{~S}$ donors induce toxicity through the rapid release of gas, some bioalternatives approaches are recommended.

Furthermore, the lack of a completely successful strategy in the application of iron sulfide (FeS) NZs, the use of anti-cancer drugs such as doxorubicin (Dox), and the formation of coatings on NZs to reduce toxicity and improve targeting can increase the likelihood of success. Despite the ambiguities in the use of Dox in the treatment of breast cancer, several reports indicate that Dox causes breast cancer cell death by increasing ROS and overexpression of Fass, Bax and caspase-3 $[6,8,28,29]$. On the other hand, various results show that the challenge of Dox toxicity on heart cells $[8,30]$ and on the other hand the drug resistance of cancer cells by nanocarriers with bovine lactoferrin (bLf) coating is significantly reduced [31, 32].

In this study, not only the synthesis of FeS-Dox@bLf NZs was investigated to synchronize chemotherapy and gas therapy, but also the toxicity and drug loading along with the level of $\mathrm{H}_{2} \mathrm{~S}$ and radical release were investigated. Also, in this study, the condition of the tumor, the amount of Dox and Fe retention in non-target tissues, and possible damage in non-target tissues were investigated. In fact, we aimed to provide a biocompatible platform for integrating therapeutic activities with minimally invasive approach in order to reduce the therapeutic resistance of breast cancer cells and their effective treatment (Fig. 1).

\section{Material And Methods}

\subsection{Materials}

$\mathrm{Fe}\left(\mathrm{NO}_{3}\right)_{3} \cdot 9 \mathrm{H}_{2} \mathrm{O}$, chloroacetic acid, $\mathrm{NaOH}$, thiourea, 1-ethyl-3-(3-dimethylaminopropyl) carbodiimide (EDC), $\mathrm{N}$-hydroxysuccinimide (NHS), dimethyl sulfoxide (DMSO), methylene blue (MB), and polyvinylpyrrolidone were prepared from the Merck (Germany). Dulbecco's Modified Eagle Medium (DMEM) cell culture, MTT powder [3-(4,5-dimethylthiazol-2-yl)-2,5-diphenyltetrazolium bromide] and fetal bovine serum (FBS) were bought from Gibco (Scotland). bLf and Dox were obtained from the Sigma Aldrich (USA) and Annexin-V kit was purchased from lq products, Poland.

\section{Cinthnaic nf Ena hhlf NZS \\ Loading [MathJax]/jax/output/CommonHTML/jax.js}


Initially, a three-core Fe was provided to produce FeS NZs. In this regard, A chloroacetate solution produced from $\mathrm{ClCH}_{2} \mathrm{COOH}(5 \mathrm{~g}, 54 \mathrm{mmol})$ and $\mathrm{NaOH}(2.2 \mathrm{~g}, 55 \mathrm{mmol})$ in $100 \mathrm{ml}$ of water was gradually added to $11 \mathrm{~mL}$ of $\mathrm{Fe}\left(\mathrm{NO}_{3}\right)_{3} \cdot 9 \mathrm{H}_{2} \mathrm{O}(11 \mathrm{~g}, 27.5 \mathrm{mmol})$ solution. After 3 hours, the red solution was filtered and kept at $21^{\circ} \mathrm{C}$ for 2 weeks. Then, the precipitated red crystals were washed with cold methanol and airdried. The resulting red crystals ( $420 \mathrm{mg} ; 0.45 \mathrm{mmol}$ ) were dissolved in $35 \mathrm{ml}$ of water, followed by addition of $10 \mathrm{ml}$ of aqueous solution containing $110 \mathrm{mg}(1.45 \mathrm{mmol})$ of thio-urea and $700 \mathrm{mg}$ of polyvinylpyrrolidone by stirring. Afterwards, the clear solution was kept into an autoclave with $150^{\circ} \mathrm{C}$ (increase by $5^{\circ} \mathrm{C}$ per $\mathrm{min}$ ) for $14 \mathrm{~h}$. Finally, the FeS NZs was gathered via centrifugation ( $7000 \mathrm{~g}$ in 10 min), washed several times with methanol, and air-dried. The FeS NZs synthesis process was performed under oxygen-free conditions in a nitrogen atmosphere, as well as in oxygen-free water produced by boiling the solution and cooling it under a stream of free nitrogen.

Then, a mixture $300 \mu \mathrm{l}$ of $15 \mathrm{mg} / \mathrm{ml} \mathrm{EDC,} 300 \mu \mathrm{l}$ of $15 \mathrm{mg} / \mathrm{ml} \mathrm{NHS}$, and $10 \mu \mathrm{l}$ of $1 \mathrm{M} \mathrm{NaOH}$ were used to organize carboxyl linkers on the FeS NZs for creating bLf. In this field, $1 \mathrm{mg}$ of FeS NZs was sonicated for 20 min in $300 \mu \mathrm{L}$ of the solution prepared. Then, surplus EDC and NHS was removed using PD-10 column attenuated with $10 \mathrm{mM}$ PBS solution. Afterwards, $300 \mu \mathrm{l}$ of $1 \mathrm{mg} / \mathrm{ml} \mathrm{bLf}$ was inserted to the activated FeS NZs and preserved overnight at $21^{\circ} \mathrm{C}$. Finally, centrifugation $(5000 \mathrm{~g}$, at $5 \mathrm{~min}$ ) and DI water were applied to detach the FeS@bLf. After the production of FeS@bLf, 3 mg of FeS@bLf was mixed with 3 ml of DMSO solution containing $3 \mathrm{mg}$ of Dox for loading the Dox into the NZs. Then, the NZs were dried under vacuum for 24 hours. Ultimately, PBS was applied to wash the NZs 3 times to remove the discharged Dox via shaking for a $1 \mathrm{~min}$ at a time.

\subsection{Characterization Of Fes-dox@blf Nzs And Loading Efficacy}

The FeS-Dox@bLf morphology was considered using a field emission scanning microscope (FE-SEM, JEOL-6700, Japan). As well, transmission electron microscope (TEM) image was provided on a highresolution TEM (HRTEM, JEM-2010) at an accelerating voltage of $200 \mathrm{kV}$. Moreover, the hydrodynamic size and zeta potential of FeS-Dox@bLf were measured by Zetasizer Nano-ZS (Malvern instruments, Worcestershire, United Kingdom). $10 \mu \mathrm{l}$ of FeS-Dox@bLf was dispersed in 10 mM phosphate bufferedsaline solution (PBS, pH 3, 7 and 9). Furthermore, infrared spectra with a Nicolet model 759 FTIR spectrometer were evaluated in wavenumbers from 4000 to $500 \mathrm{~cm}^{-1}$ by applying a $\mathrm{KBr}$ wafer. The fluorescence spectra (Hitachi F 2500 spectrophotometer) were applied to evaluate the loading capacity of Dox in nanoplatform. In order to, $250 \mu \mathrm{g}$ of FeS@bLf was supplemented to Dox solution at diverse concentrations $(50,100,150,200$ and $250 \mu \mathrm{g})$, and blended by shaking at $21^{\circ} \mathrm{C}$ for $24 \mathrm{~h}$. Then, nanozymes containing the Dox were detached from the solution by a magnet. The loading efficiency (\%) was then determined by Loading efficiency $(\%)=(A-B / B) \times 100$, Where $A$ is the total amount of Dox, and $B$ is the amount of Dox remaining in the solution. 


\subsection{Hydroxyl Radical Catalysed By Fes-dox@blf}

The photocatalytic degradation of MB by FeS-Dox@bLf was performed at $22^{\circ} \mathrm{C}$ using $40 \mathrm{~mL} \mathrm{MB}$ aqueous solution $\left(6 \times 10^{-6} \mathrm{M}\right)$ containing $30 \mathrm{mM} \mathrm{NaHCO}_{3}$ and $11 \mathrm{mM} \mathrm{H}_{2} \mathrm{O}_{2}$, and $20 \mathrm{mg}$ of FeS-Dox@bLf with continuous stirring in a dark flask for $30 \mathrm{~min}$ to light irradiation. Then, suspension was brightened with the tungsten halogen lamp (200 W). During the determined time periods, $3 \mathrm{~mL}$ of the aliquot was removed from the mixture and centrifuged and the dye concentration was measured with an UV-vis spectrophotometer in the range of $500-800 \mathrm{~nm}$.

\subsection{Fe, Hs And Drug Release}

To determine the level of $\mathrm{Fe}^{+}$released, $450 \mu \mathrm{L}$ of FeS-Dox@bLf $(6 \mathrm{mM})$ was added into a dialysis bag with PBS buffer $(60 \mathrm{~mL}, 12 \mathrm{mM})$ at $\mathrm{pH} 6.5$ and 7.2. The solutions were maintained stirring at $37^{\circ} \mathrm{C}$ and 3 $\mathrm{mL}$ was collected for analysis at $0,0.5,1,2,5,8,16,24,48$, and 72 hours. The Fe elements were quantified using atomic absorption spectrophotometry. Likewise, for evaluating $\mathrm{H}_{2} \mathrm{~S}, 450 \mu \mathrm{L}$ of FeSDox@bLf NZs (6 mM) was added into a dialysis bag with HEPES buffer $(60 \mathrm{~mL}, 12 \mathrm{mM})$ at pH 6.5 and 7.2. Then, $2 \mathrm{~mL}$ of the solution was gathered for $\mathrm{H}_{2} \mathrm{~S}$ analysis at $0,1,2,5,10,20,30,40,50,60 \mathrm{~min} . \mathrm{H}_{2} \mathrm{~S}$ concentration was evaluated using a standard MB method based on the description of Lin et al. [33]. In this regard, $120 \mu \mathrm{L}$ of the solution with $120 \mu \mathrm{L}$ of $1 \%(\mathrm{w} / \mathrm{v})$ zinc acetate, $24 \mu \mathrm{L}$ of DMPD $(21 \mathrm{mM}$ in $7.3 \mathrm{M}$ $\mathrm{HCl})$ and $24 \mu \mathrm{L}$ of $\mathrm{FeCl}_{3}(32 \mathrm{mM}$ in $1.3 \mathrm{M} \mathrm{HCl})$ were mixed, maintained at $21^{\circ} \mathrm{C}$ for $20 \mathrm{~min}$, and the optical density at $665 \mathrm{~nm}$ was calculated. A standard curve was fixed with predetermined $\mathrm{H}_{2} \mathrm{~S}$ concentrations. Then, the calibration curve was applied to estimate the $\mathrm{H}_{2} \mathrm{~S}$ concentration.

To investigate the possibility of in vitro drug release from NZs, the FeS-Dox@bLf NZs were incubated at $37^{\circ} \mathrm{C}$ for 15 hours in PBS at different pH (6.5 and 7.2). Generally, certain amounts of NZs were diffused in $10 \mathrm{~mL}$ of PBS and put in the dialysis bag (MWCO 3500). Afterwards, the bag was dialyzed against $45 \mathrm{~mL}$ of the same buffer at $120 \mathrm{rpm}$. At designated times, $6 \mathrm{~mL}$ of solution the dialysis bag was withdrawn for the investigation via absorbance at $490 \mathrm{~nm}$ and was replaced by an equal volume of the same buffer. The Dox cumulative release was assessed based on the following Eq. (1):

Cumulative drug release $(\%)=\frac{6 \times \sum_{\mathrm{i}-1}^{\mathrm{n}-1} \mathrm{C}_{\mathrm{i}}+\mathrm{V} \times \mathrm{C}_{\mathrm{n}}}{\text { weightofDoxonFeS } @ \mathrm{bLf}} \times 100$ Eq. (1)

Where, $C_{i}$ and $C_{n}$ refer to the of Dox concentration at time $i$ and $n$, and $\mathrm{V}$ was the volume of the buffer in the drug release experiment, respectively.

\subsection{In vitro trials}

The $4 \mathrm{~T} 1$ cells were seeded in DMEM medium with $10 \% \mathrm{FBS}, 100 \mathrm{U} / \mathrm{mL}$ of penicillin, and $100 \mu \mathrm{g} / \mathrm{mL}$ of streptomycin and preserved in an incubator with $5 \% \mathrm{CO} 2$ at $37^{\circ} \mathrm{C}$ and $95 \%$ humidity. To transfer $4 \mathrm{~T} 1$ 
cancerous cells to a new culture medium, the cells were trypsinized with $0.25 \%$ trypsin-EDTA and resuspended in DMEM medium.

\subsubsection{In vitro combination therapy}

The $4 \mathrm{~T} 1$ cells were cultured at a density of $3 \times 10^{5}$ cells per well into 96 -well plate and then incubated for 12 hours at $37^{\circ} \mathrm{C}$ with $5 \% \mathrm{CO}_{2}$. After $12 \mathrm{~h}$, the $4 \mathrm{~T} 1$ cells was treated and incubated for 24 hours (main incubation) with different concentrations of free Dox $(5,10,15,20$, and $25 \mu \mathrm{g} / \mathrm{mL}), F e S @ b L f ~ N Z s$ and FeS-Dox@bLf NZs $(12.5,25,37.5,50$ and $62.5 \mu \mathrm{g} / \mathrm{mL})$ without or with laser irradiation $\left(150 \mathrm{~J} / \mathrm{cm}^{2}\right.$ fluence and $100 \mathrm{~mW} / \mathrm{cm}^{2}$ irradiance) for $7 \mathrm{~min}$ in 8th hour after main incubation. In the following, the medium was eliminated by PBS, and $0.6 \mathrm{mg} / \mathrm{mL}$ MTT was diffused in media and incubated for 4 hours ( $50 \mu \mathrm{L}$ per well). After incubation, the culture medium was removed and the residual crystals were dissolved in $100 \mu \mathrm{L}$ DMSO by shaking for $2 \mathrm{~min}$. Then, cells were evaluated at $\lambda=570 \mathrm{~nm}$ by applying the Eq. (2):

$\%$ Cell viability $=\left(\mathrm{NS}_{\text {absorbance }} / \mathrm{NC}_{\text {absorbance }}\right) \times 100 \mathrm{Eq} .(2)$

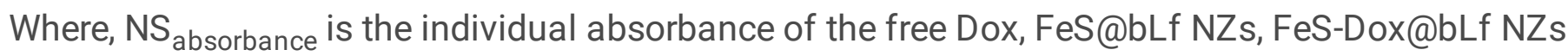
without and with laser irradiation loaded well and $\mathrm{NC}_{\text {absorbance }}$ is the mean absorbance of control well. Mean standard deviations were calculated for each well.

\subsubsection{Cellular Concentration Of Hydroxyl Radical And Hs}

Similar to the 2.6 .1 section, $4 \mathrm{~T} 1$ cells $\left(5 \times 10^{5}\right.$ cells per well) were harvested into 6 -well plates and incubated for 12 hours at $37^{\circ} \mathrm{C}$ and $5 \% \mathrm{CO}_{2}$. Subsequently, the medium was treated by FeS@bLf NZs $(12.5,25,37.5,50$ and $62.5 \mu \mathrm{g} / \mathrm{mL})$ and incubated for 24 hours. During the incubation, the $4 T 1$ cells were treated by laser irradiation for $7 \mathrm{~min}$ in the 8th hour after incubation. Ultimately, the medium was eliminated and the fluorescence probe ( $30 \mu \mathrm{M}$ of non-fluorescent DCFH-DA) was supplemented to reduce hydroxyl radical ( $(\mathrm{OH})$ for 30 min. Eventually, the fluorescent intensity of dichlorofluorescein (DCF) was investigated using a fluorescence spectrometry with a wavelength of excitation and emission of 495 and $525 \mathrm{~nm}$, respectively. For intercellular $\mathrm{H}_{2} \mathrm{~S}, 5 \times 10^{5} 4 \mathrm{~T} 1$ cancer cells per well were cultured into 6 -well plates for 12 hours. After incubation, Wahington State Probe- $1\left(\mathrm{C}_{33} \mathrm{H}_{21} \mathrm{NO}_{6} \mathrm{~S}_{2}\right)(15 \mu \mathrm{M})$ was applied as $\mathrm{H}_{2} \mathrm{~S}$ probe for $30 \mathrm{~min}$ and the same time $4 \mathrm{~T} 1$ cells were treated with $12.5,25,37.5,50$ and $62.5 \mu \mathrm{g} / \mathrm{mL}$ of FeS@bLf without or with laser irradiation in 8th hour of main incubation. Consequently, the 4T1 cells were washed with PBS and evaluated by fluorescence intensity of the probe.

\subsubsection{Apoptosis And Ros Assays}

To evaluate of apoptosis in the presence of free Dox $(20 \mu \mathrm{g} / \mathrm{mL})$, FeS-Dox@bLf NZs and FeS-Dox@bLf Loading [MathJax]/jax/output/CommonHTML/jax.js ; used. Based on the method described above, 4T1 cells 
( $5 \times 10^{5}$ cells per well) were located into a 6-well plate and treated with drugs and NZs with (in 8th hours of main incubation) or without laser irradiation in the incubator for 24 hours. Then, the cells were gathered with $3000 \mathrm{~g}$ centrifugation at $4^{\circ} \mathrm{C}$ for $3 \mathrm{~min}$, and washed with PBS. Then, the $4 \mathrm{~T} 1$ cells were resuspended in $100 \mu \mathrm{L}$ per tube of containing Annexin V binding buffer (HEPES buffer: $0.1 \mathrm{M}, \mathrm{NaCl} 1.4 \mathrm{M}, \mathrm{CaCl}_{2} 25$ $\mathrm{mM}, \mathrm{pH}$ 7.4). In the following, $2 \mu \mathrm{L}$ of Annexin $\mathrm{V}$ conjugated Alexa Fluor 488 was added to the cells solution and retained in dark for $15 \mathrm{~min}$ at $21^{\circ} \mathrm{C}$. Afterwards, $400 \mu \mathrm{L}$ of the binding buffer and $5 \mu \mathrm{l}$ of 50 $\mu \mathrm{g} / \mathrm{ml}$ propidium iodide were added to the solution and reserved in ice. Finally, samples were analysed by FACscan (BD Bioscience, USA).

Similar to ${ }^{\circ} \mathrm{OH}$ assay in 2.6 .2 section, to determine intracellular ROS in the presence of free Dox (20 $\mu \mathrm{g} / \mathrm{mL})$, FeS-Dox@bLf NZs and FeS-Dox@bLf NZs + Laser $(50 \mu \mathrm{g} / \mathrm{mL}), 5 \times 10^{5} 4 \mathrm{~T} 1$ cancerous cells per well were cultured into 6-well plate for 24 hours. Then, the fluorescent intensity based on DCF measurement was evaluated.

\subsection{In vivo trials}

For in vivo studies, 40 mice in 5 groups were used. For this purpose, 7-weekly mice, weighing $25.6 \pm 1.3 \mathrm{~g}$ were kept at $25^{\circ} \mathrm{C}$ with 12 hours of light, $55 \%$ of humidity and free access to water and feed. The cultured $4 \mathrm{~T} 1$ cancerous cells $\left(1 \times 10^{6}\right.$ cell) according to 2.6 section were injected subcutaneously $(150 \mu \mathrm{l}$,$) at the$ end of the mammary gland on the right side of the mice. After the tumors reached a size of $144.1 \pm 2.4$ $\mathrm{mm}^{3}$, they were treated with free Dox $(10 \mathrm{mg} / \mathrm{kg})$ and FeS-Dox@bLf NZs $(20 \mathrm{mg} / \mathrm{kg})$ with and without laser irradiation. The amount of Dox injection in free and FeS-Dox@bLf NZs conditions was equal.

\subsubsection{Body Weight And Tumour Size}

The mice were orderly monitored for abnormal behavior and were weighed every four days. Also, to measure the tumor volume (TV), the mice were evaluated in each measurement by the digital vernier caliper (Mitutoyo, Japan) based on Eq. (3):

TV $\left(\mathrm{mm}^{3}\right)=1 / 2 \times\left(\right.$ length $\times$ width $\left.^{2}\right)$ Eq. (3)

Furthermore, mice were sacrificed on day 18 , and the tumours were collected and weighed.

\subsubsection{Photodynamic Therapy (Pdt)}

For PDT assay, the tumor was illuminated for $7 \mathrm{~min}$ with light of a $150 \mathrm{~J} / \mathrm{cm}^{2}$ fluence and $100 \mathrm{~mW} / \mathrm{cm}^{2}$ irradiance by applying a diode laser. Light with a wavelength of $570 \mathrm{~nm}$ to the entire tumor was set up to prevent possible damage. 
For studying the Doxo concentration in main organs including heart, spleen, liver, lung and breast tumor tissues, the samples were collected, washed with cold saline and dried. Then, tissues were homogenized in an acetonitrile and water (50:50) mixture for liquid-liquid phase extraction explained by Zhang et al. [34].

Fluorescent imaging with FlouVision (16MP CCD camera) device was used to investigate the biodistribution of the Dox in the whole body and main organs. For this purpose, to determine the distribution of the Dox in the whole body, after 8 hours from drug injection, the mice were anesthetized and fluorescence imaging was performed with excitation $485 \mathrm{~nm}$ and emission $590 \mathrm{~nm}$. Likewise, to image the Dox distribution in vital organs, mice were sacrificed in 8 hours after injection and their vital organs were collected and after washing with $0.9 \% \mathrm{NaCl}$, ex vivo fluorescence was used with the same device settings.

\subsubsection{Excrete And Distribution Of Fe}

In order to evaluate the concentration of excreted Fe via urine and faces, the animals were placed in metabolic glass cages. Faecal and urinary samples were collected 48 hours and Fe concentration was determined on days 0 (to determine the background level), 8 and 16 days after FeS-Dox@bLf NZs administration. The amount of Fe in the samples was determined using atomic absorption spectrophotometry. Moreover, to evaluate the Fe distribution in tissues of tumor, heart, lung, spleen and liver, microwave digestion technique with mixture $\mathrm{HNO}_{3}: \mathrm{HClO}_{4}(5: 1)$ was applied. Then, $0.2 \mathrm{~g}$ of digested samples was diluted with $50 \mathrm{ml}$ of deionized water, and finally Fe elements were measured by atomic absorption spectrophotometry.

\subsubsection{Histological Assay}

For histopathological evaluation of major organs including heart, liver, spleen, lung, and tumor, the mice were sacrificed and their organs were collected at the end of experiments. Formaldehyde (10\%) was used to fix the tissue samples and then continued by passage and embedding in paraffin. To perform the hematoxylin and eosin (H\&E) staining operation, paraffin blocks were partitioned by $3 \mu \mathrm{m}$ thickness.

Slides were studied at the microscopic (Olympus-BX51 microscope), then an Olympus-DP12 camera was used to gain digital photos and graded by the Scharff-Bloom-Richardson Scale.

\subsection{Statistical Analysis}

Statistical analysis was carried out with one-way ANOVA followed by least square means and statistical differences were measured at level of ${ }^{\star} P<0.05,{ }^{\star \star} P<0.01$ and ${ }^{\star \star \star} P<0.001$. 


\subsection{FeS-Dox@bLf NZs characterization}

The morphological properties of the FeS-Dox@bLf NZs produced were initially investigated by SEM and TEM. As shown in Fig. 2A and B, the FeS-Dox@bLf NZs are spherical with a size of $35 \mathrm{~nm}$, and also the Lf coating covers them well. The SEM and TEM images show the relatively normal distribution of FeSDox@bLf NZs during synthesis. On the other hand, the particle size diagram obtained by the DLS method in Fig. $2 \mathrm{C}$ shows that the size of FeS with dimensions of 5 to $70 \mathrm{~nm}$ in the presence of bLf increased to 10 to $75 \mathrm{~nm}$. Therefore, the formation of bLf coating on FeS can be confirmed by increasing the particle size to at least $5 \mathrm{~nm}$. The zeta potential data in Fig. 2D indicate that theta nanoparticles have zeta potentials of $+9.1,-3.9$ and $-10.3 \mathrm{mV}$ at $\mathrm{pH} 3,7$ and 9, respectively, which can be part of the surface charge related to amino groups. Whereas, the zeta potential values for iron nanoparticles in acids 3,7 and 9 were $-2.8,-7.1$ and -18.9 , respectively. Thus, not only did the zeta potential confirm the presence of protein on iron nanoparticles, but these results also confirmed the adequate colloidal stability of iron nanoparticles in biological and environmental applications. In this regard, the results of FT-IR on FeS, Dox, bLf and FeS-Dox@bLf confirm the loading of drug and bLf on the NZs. FT-IR spectra in Fig. 2E showed that Dox had a peak on $3382 \mathrm{~cm}^{-1}(\mathrm{~N}-\mathrm{H}), 2923 \mathrm{~cm}^{-1}(\mathrm{C}-\mathrm{H}), 1719 \mathrm{~cm}^{-1}(\mathrm{C}=\mathrm{O})$, bending $1516 \mathrm{~cm}^{-1}(\mathrm{~N}-\mathrm{H})$, $1413 \mathrm{~cm}^{-1}(\mathrm{C}-\mathrm{C}), 1288 \mathrm{~cm}^{-1}$ (C-O-C), $1073 \mathrm{~cm}^{-1}(\mathrm{C}-\mathrm{O})$, and 891 or $782 \mathrm{~cm}^{-1}(\mathrm{~N}-\mathrm{H})$ indicates. Nonetheless, when Dox was conjugated on the FeS-Dox@bLf, the N-H, C = O, C-O-C and N-H peaks which was observed in the Dox spectrum was disappeared. Also, the bonds of amide in bLf represented the main feature of bending and stretching vibrations as amide I, II, III, and A (1635, 1539, 1069, and 3266 respectively), which the intensity of amide I and II peak were reduced in the FeS-Dox@bLf. The results of drug loading capacity (\%) revealed that with rising Dox concentration, despite the constant concentration of FeS@bLf $\mathrm{NZs}(250 \mu \mathrm{g} / \mathrm{mL})$, the amount of drug loading in nanozyme meaningfully increases (Fig. 2F). While, the loading efficiency (\%) decreases with rising Dox concentrations. This profile proposes that the highest Dox loading in FeS@bLf NZs can be attained in the range of $100 \mu \mathrm{g} / \mathrm{mL}$ with an efficiency of $~ 58 \%$.

The metallic nanozymes organize the catalysts for Fenton reaction in the blood, which can use $\mathrm{H}_{2} \mathrm{O}_{2}$ in tumors to produce ${ }^{\circ} \mathrm{OH}$. In order to explore the peroxidase-like behavior of FeS-Dox@bLf NZs, after adding NZs to a solution containing MB and $\mathrm{H}_{2} \mathrm{O}_{2}$ for 180 min, it was found that FeS-Dox@bLf NZs as a nanozyme change blue color and gradually reduce the peak in the range of 600 to $700 \mathrm{~nm}$ by digesting MB (Fig. 3A). Color change with reducing methylene blue confirms the time-dependent enzymatic activity of FeS-Dox@bLf.

\subsection{Fe, Hs And Dox Release}

To evaluate the degradability of FeS-Dox@bLf NZs in blood and tumor tissue, NZs were examined in aqueous medium with pH 6.5 and 7.2. As shown in Fig. 3B, FeS-Dox@bLf NZs not only decompose faster in an acidic environment, but also release higher $\mathrm{Fe}^{2+}$. For example, after 8 hours, the level of $\mathrm{Fe}^{2+}$ released in the acid medium was hiqher than $80 \%$, while the level of $\mathrm{Fe}^{2+}$ released in the neutral medium Loading [MathJax]/jax/output/CommonHTML/jax.js 
was up to $40 \%$. However, the level of $\mathrm{Fe}^{2+}$ release from $8 \mathrm{~h}$ onwards is almost constant in both neutral and acidic conditions. This result indicates the possibility of $\mathrm{Fe}^{2+}$ release in $4 \mathrm{~T} 1$ tumor cells.

Likewise, to survey $\mathrm{H}_{2} \mathrm{~S}$ release, FeS-Dox@bLf NZs were dispersed in PBS at pH 6.5 and 7.2 for 60 min. The results of Fig. $3 \mathrm{C}$ show a significant increase in $\mathrm{H}_{2} \mathrm{~S}$ release by changing the acidity of the environment from neutral to acidic. As expected, FeS-Dox@bLf NZs in an acidic environment $\mathrm{H}_{2} \mathrm{~S}$ release faster and more than in a neutral medium in line with the release of $\mathrm{Fe}^{2+}$. Therefore, the release of $\mathrm{H}_{2} \mathrm{~S}$ dependent on environmental acidity by FeS-Dox@bLf NZs allows the intelligent treatment and diagnosis of cancerous tumors.

As well, by examining the release of the drug at $\mathrm{pH} 6.5$ and 7.2 at $37^{\circ} \mathrm{C}$, it was determined that the Dox release from the FeS-Dox@bLf NZs based on Fig. 3D follows a time-dependent diffusion profile. The results indicated that the drug release rate in $\mathrm{pH}>7$ due to the function of bLf as a bio-gate is higher than neutral (83.3 vs. 46.4 during $900 \mathrm{~min}$ ). Despite the burst release of the Dox from FeS-Dox@bLf NZs, the rate of drug release over time is relatively constant and increasing. Above $80 \%$ Dox release from FeSDox@bLf NZs in acidic condition is a very good potential for drug release in cancerous tissues with pH 6 to 6.6 .

\subsection{In vitro trials}

Examination of free drug or NZs toxicity on 4T1 cancerous cells based on MTT technique revealed that free Dox, FeS@bLf, FeS-Dox@bLf NZs and FeS-Dox@bLf NZs + laser have a negative effect on 4T1 cells (Fig. 4A). Despite the high toxicity of FeS-Dox@bLf NZs on 4T1 cancer cells, the results of Fig. 4A show that there is no significant difference between the toxicity of free Dox and FeS@bLf at different concentrations on 4T1 cancer cells. On the other hand, the use of FeS-Dox@bLf NZs + laser exposed the most toxicity for $4 \mathrm{~T} 1$ cancerous cells compared to other groups. Overall, the results revealed that increasing the concentration of NZs and the free drug increased their toxicity.

Since part of the therapeutic effects of FeS-Dox@bLf NZs in this study are based on $\mathrm{H}_{2} \mathrm{~S}$ and 'OH release, the death rate of $4 \mathrm{~T} 1$ cancerous cells death based on $\mathrm{H}_{2} \mathrm{~S}$ and ${ }^{\circ} \mathrm{OH}$ were investigated and reported in Fig. 4B. As seen, the most toxic effects of FeS@bLf NZs on 4T1 cells death are based on ${ }^{\circ} \mathrm{OH}$ concentration, which with increasing FeS@bLf NZs concentration, the ${ }^{\circ} \mathrm{OH}$ effect is constantly reduced and added to the $\mathrm{H}_{2} \mathrm{~S}$. On the other hand, the use of lasers on FeS@bLf NZs in this study showed that $\cdot \mathrm{OH}$ accounts for a large proportion of cancer cell death $\left({ }^{*} \mathrm{P} \leq 0.05\right)$. It is generally observed that the effects of ${ }^{\circ} \mathrm{OH}$ are much more powerful than $\mathrm{H}_{2} \mathrm{~S}$ production. However, laser irradiation of NZs increases the $\mathrm{H}_{2} \mathrm{~S}$ activity in them, which indicates an increase in $\mathrm{S}^{2-}$ release and induction of more enzymatic reactions with the released $\mathrm{Fe}^{2+}$. 
In order to confirm the greater toxicity of FeS-Dox@bLf NZs with and without laser therapy compared to free Dox in therapeutic activities, apoptosis and ROS experiments (Fig. 4C and D) demonstrated that FeSDox@bLf NZs with and without laser provided the highest toxicity and cancer cell death compared to free Dox. For instance, apoptotic cells percentage in 4T1 cancer cells after $24 \mathrm{~h}$ indicated that FeS-Dox@bLf NZs, compared to the free Dox group, increased the induction of apoptosis in Q2 and Q3 quarters from 25.1 to $29.2 \%\left({ }^{\star \star *} \mathrm{P} \leq 0.001\right)$ and from 28.6 to $31.7 \%\left({ }^{\star \star *} \mathrm{P} \leq 0.001\right)$, respectively. Whereas the use of laser significantly increased 4T1 cells death and induced apoptosis from 29.2 to $42.8 \%$ (Q2) and from 31.7 to 33.4\% (Q3). In this regard, our results in Fig. 4D confirmed the toxicity of FeS-Dox@bLf NZs compared to the free Dox by increasing the intracellular ROS. It can also be seen that the ROS level in the use of laser on the platform of FeS-Dox@bLf NZs is almost 3.03 folds than that of the control group, 1.84 times that of free Dox and 1.35 folds than that of FeS-Dox@bLf NZs.

\subsection{In vivo trials}

Because the results of the in vitro method were considered favorable, cancer mice were used to evaluate the therapeutic effects of FeS-Dox@bLf NZs with or without laser irradiation in vivo condition. There was no significant difference in the weight of mice during the experimental period (Fig. 5A). However, compared to other groups, control mice had a higher rate of tumor growth. The results of Fig. 5B revealed that the integration of chemotherapy with gas therapy by FeS-Dox@bLf NZs causes a significant difference compared to the control and free Dox groups. In this regard, the use of laser irradiation on the platform of FeS-Dox@bLf NZs according to raising ROS increased the efficiency of treatment and significantly reduced the volume of breast tumors compared to free Dox and even FeS@bLf NZs. Furthermore, the results of Fig. 5C and D confirmed that the combination of chemotherapy and PDT reduces tumor volume by up to $\sim 6.2$ fold than the control group, $\sim 2.84$ fold than the free Dox and $\sim 1.77$ times the FeS-Dox@bLf NZs at the end of experimental period.

As shown in Fig. 6A, Dox accumulation by FeS-Dox@bLf NZs was significantly increased in tumor tissue compared to free Dox. Although the use of nanocarriers increased drug delivery from non-target tissues to the tumor, it significantly reduced drug levels in heart, spleen and lung tissues. Likewise, the fluorescent intensity results in Fig. 6B revealed that Dox-wide distribution throughout the whole body using the FeSDox@bLf NZs focuses on tumor tissue. While the distribution of free Dox throughout the body is more widespread. On the other hand, the intensity of fluorescent in vital organs shows that the use of FeSDox@bLf NZs increases the intensity of fluorescent in tumor tissue and decreases the intensity of fluorescent in the organs of the heart and spleen (Fig. 6C). However, no significant difference in fluorescent intensity was observed in liver and lung tissue. Therefore, the use of FeS-Dox@bLf NZs can reduce the level of toxicity of the Dox by reducing their accumulation in vital tissues. Overall, the results of Fig. 6 show the successful targeting of nanoplatform-based drugs.

In the following, the results of Fig. 7B show an increase in Fe accumulation in tumor tissue compared to tho mantral arnun Wharase doenits tha lank of significant differences in Fe accumulation in liver and lung Loading [MathJax]/jax/output/CommonHTML/jax.js 
tissues, the results expose that heart and spleen tissues were effective in Fe retention. In addition, to evaluate Fe of urine plus faces, the results of Fig. 7A show that the injected NZs can be excreted from the body within 24 hours, considering the amount retained in the tissues of the spleen, lungs and heart. This result therefore explains that the amount of Fe received from the body is excreted and the level of toxicity is greatly reduced.

Finally, a histological method was used to evaluate cytotoxicity in the liver, heart, lung and spleen organs. As shown in Fig. 7C, the use of free Dox causes adverse changes in heart tissue. While the use of FeSDox@bLf NZs with and without irradiation laser shows, the adverse effects of the drug on heart tissue are greatly reduced. It was also found that the use of different treatments did not cause significant damage to liver, spleen and lung tissue. However, analysis of tumor tissues reveals that the most important morphological changes in 4T1 tumor cells are caused by FeS-Dox@bLf NZs + Laser. However, changes in tumor tissue in the FeS-Dox@bLf NZs group versus free Dox are significant and remarkable. Staining results showed that the tumor tissue structure had disappeared in free Dox, FeS-Dox@bLf NZs with and without laser irradiation, and that some of the remaining breast cancer cells had shrunk (Fig. 7C). Typically, cancer cells appear brown with a state of necrosis or apoptosis, and live cells appear pink.

\section{Discussion}

Nowadays, the use of magnetic NPs with protein coating to target in medical activities due to the ability to synchronize an auxiliary's therapies such as PTT, PDT, with chemotherapy are highly regarded [35-37]. Therefore, to control and therapy breast cancer, we designed relatively uniform FeS NZs based on the results of the SEM, TEM and DLS (Fig. 2), which was confirmed by the FTIR results (Fig. 2D). The physicochemical properties of FeS NZs were consistent with the findings of Sathiyaraj and Thirumaran [38] and Yang et al. [39]. On the other hand, the results of SEM, TEM and FTIR similar to the outcomes of Shankaranarayanan et al. [40] and Sharifi et al. [8] showed that bLf and Dox were loaded on FeS NZs.

Metallic NPs such as Fe, manganese (Mn), copper (Cu), etc. as nanozymes are able to perform chemical reactions in biological solutions $[9,41,42]$. On the other hand, it has been confirmed that amorphous metallic NZs especially Fe NZs perform better Fenton reactions than bare NZs due to higher ionization and release of metal ions [43]. Therefore, parallel to the activities of He et al. [44] who showed that NH2MIL-88B(Fe) NZs change the color of MB by producing 'OH caused by Fenton reactions, in this study it was found that FeS@bLf NZs over time cause the digestion of MB in the presence of $\mathrm{H}_{2} \mathrm{O}_{2}$ and discoloration (Fig. 3A). Digestion of MB in the presence of FeS-Dox@bLf indicates the peroxidase-like activity of NZs with the release of $\mathrm{Fe}^{2+}$, which was in agreement with the finding of Xie et al. [45]. Furthermore, the outputs of this report (Fig. 3A) similar to the results of Maji et al. [46] exhibit that the enzyme-like activities of FeS@bLf NZs are highly dependent on the duration of the presence of NZs, such as concentration, crystalline nature and particle size of NZs $[47,48]$.

Since it has been proven that the release of metal ions increases their enzyme-like activity [47], inducing 
accordance with the results of Xie et al. [45], this study revealed that FeS-Dox@bLf NZs release $\mathrm{Fe}^{2+}$ in acidic conditions in a favorable manner, which has been significantly effective in therapeutic activity (Fig. 3B). Likewise, He et al. [26] explained that MnS@BSA NZs increased enzyme-like activity by releasing $\mathrm{Mn}^{2+}$ under acidic conditions. In this regard, the $\mathrm{H}_{2} \mathrm{~S}$ release at pH 6.5 indicated an increase in the release of $\mathrm{Fe}^{2+}$ along with $\mathrm{S}^{2-}$ from FeS-Dox@bLf NZs (Fig. 3C). Similar to our findings, Ma et al. [49] and Kou et al. [50] explained that release of $\mathrm{Cu}^{2+}$ and $\mathrm{Fe}^{2+}$ from the metal-organic framework and Fe@carboxymethyl cellulose NPs, respectively, increase gas release in acidic condition compared to neutral condition. Moreover, comparable to the results of other findings [26, 45], this report suggests that the use of protein coatings such as bLf delays the burst release of $\mathrm{H}_{2} \mathrm{~S}$ to further load NZs into cancer cells. Along with $\mathrm{Fe}^{2+}$ release, releasing $\mathrm{H}_{2} \mathrm{~S}$ from FeS-Dox@bLf NZs in acidic condition is more than neutral, which can be very important in cancer treatment activity due to the tumor microenvironmental acidic conditions. In addition to the release of $\mathrm{Fe}^{2+}$ and $\mathrm{H}_{2} \mathrm{~S}$, Dox loaded on FeS-Dox@bLf NZs will be very effective on therapeutic activity. In agreement with the results of Singh et al. [51], Sharifi et al. [6], and Sharifi et al. [8] Fig. 3D shows that the release of Dox from FeS-Dox@bLf NZs increases with decreasing environmental acidity. Analogous to the release of $\mathrm{Fe}^{2+}$ and $\mathrm{H}_{2} \mathrm{~S}$, the mechanism of release of Dox from FeS-Dox@bLf NZs into cells can be related to the effect of lysosome activity, the acidic condition of the tumor microenvironment, and endosome activity.

The toxic effects of FeS-Dox@bLf NZs with and without laser irradiation in Fig. 4A indicated that their negative effects on 4T1 cancer cells are dose-dependent. This finding, together with the results of the effect of $\mathrm{NZs}$ on the increase of ${ }^{\circ} \mathrm{OH}$ and $\mathrm{H}_{2} \mathrm{~S}$ through $\mathrm{Fe}^{2+}$ catalytic activity (Fig. 4B), are in agreement with the results of Xie et al. [45] and Xiao et al. [52], which generally all point to the induction of apoptosis via ROS with intracellular biological changes such as DNA damage and mitochondrial dysfunction [53]. Although the lethal level of $\mathrm{H}_{2} \mathrm{~S}$ on $4 \mathrm{~T} 1$ cancerous cells is less important than ${ }^{\circ} \mathrm{OH}, \mathrm{H}_{2} \mathrm{~S}$ induces apoptosis by increasing the intracellular ROS through the Fenton reaction of $\mathrm{Fe}^{2+}$ due to the cessation of catalase activity [54] and excessive accumulation of $\mathrm{H}_{2} \mathrm{O}_{2}$ [55]. Moreover, in line with the result of Chang et al. [56], this study revealed that the synergy of chemotherapy with PDT increases intracellular ROS and apoptotic cellular death.

In vivo evaluations in this study (Fig. 5) are similar to the studies of She et al. [57] and Xie et al. [45] confirming the significant effects of FeS-Dox@bLf NZs on the size and volume of breast tumors. Numerous anti-tumor activities of drug-containing Fe NPs in breast cancer have been published parallel to this report $[6,8,58-60]$, which in addition to reducing drug resistance through intelligent drug delivery increased the performance of anti-cancer activity by synchronizing PTT or PDT. Increased performance of FeS-Dox@bLf NZs is not only related to PDT to induce apoptosis through $\mathrm{H}_{2} \mathrm{~S}$, but also the results of Fig. 6 show that increasing the load of Dox via FeS-Dox@bLf NZs on breast tumors indicates that they are more effective in treating breast cancer. Consistent with this finding, Sharifi et al. [6] and Sharifi et al. [8] showed that Dox focused more on breast cancer tissue using Fe NPs compared to the control group. Loading [MathJax]/jax/output/CommonHTML/jax.js metallic NZs containing drug in tumor therapy is similar to 
the finding of Fang et al. [61] who showed that the effect of gas therapy to reduce drug resistance is very significant.

Subsequently, in vivo evaluation based on the results of Fig. 6A demonstrated that Dox accumulation was significantly reduced in non-target tissues, especially in the heart, by targeting the drug with FeSDox@bLf NZs, which was in line with the outcomes of Tang et al. [62] and Wang et al. [63]. This reduction significantly eliminates the side effects of chemotherapy. Meanwhile, Sharifi et al. [8] explained that the use of bLf coating increases the drug loading level in breast cancer tissue by twice to three times. Lack of accumulation of Fe NPs in lung and liver tissues, and excessive increase in Fe accumulation in tumor tissue can confirm the accumulation of Dox in tumor tissue. As well, the removal of Fe NPs from the body within 48 hours (Fig. 7A) analogous to the result of Mn rapid clearance from the body of mice described by $\mathrm{He}$ et al. [26] indicates a reduction in the severity of toxicity of the use of FeS in long-term activity. In another part of the study, comparable to the reports of Sharifi et al. [6] and Luo et al. [64], it was shown (Fig. 7C) that the synchronization of PDT with chemotherapy significantly destroys the cellular structure of breast tumors and enhances therapeutic activity.

\section{Conclusions}

In general, a new type of amorphous FeS-Dox@bLf NZs sensitive to environmental acidity was designed by a wet chemical method that has the ability to synchronize chemotherapy and PDT to enhance $\mathrm{H}_{2} \mathrm{~S}$ production for the treatment of breast cancer. During synthesis, it was determined that FeS-Dox@bLf NZs show peroxidase-like activity in acidic condition by releasing $\mathrm{Fe}^{2+}$ and $\mathrm{S}^{2-}$ to produce ${ }^{\circ} \mathrm{OH}$ and $\mathrm{H}_{2} \mathrm{~S}$, respectively. Therefore, the use of FeS-Dox@bLf NZs in the treatment of breast cancer with relatively acidic microenvironments can be beneficial by increasing free radicals and gas. For this purpose, evaluations of intracellular ROS and their effects on apoptotic cellular death confirmed the effects of FeSDox@bLf NZs for the treatment of 4T1 cancerous cells, which was enhanced by the synchronization of chemotherapy and PDT. Furthermore, FeS-Dox@bLf NZs with targeted transfer and further release of Dox on breast tumors based on the tumor microenvironment acidic condition have allowed the drug to be loaded, which causes less toxicity in other tissues, especially in the heart. In vivo evaluations in this study also revealed that FeS-Dox@bLf NZs are highly biocompatible for long-term treatments due to the removal of Fe from the body within 48 hours and the concentration of FeS-Dox@bLf NZs on the target tissue. Overall, all the in vitro and in vivo observations in this study determined that FeS-Dox@bLf NZs are not only successful in treating and controlling breast cancer with minimal side effects, but also it provided a clear way to synchronize different therapies such as chemotherapy, PDT, and so on.

\section{Declarations}

\section{Declarations}

Ethics approval and consent to participate

Loading [MathJax]/jax/output/CommonHTML/jax.js 
All animal use procedures were carried out in accordance with the Regulations of Experimental Animal Administration issued by the State Committee of Science and Technology of the People's Republic of China, with the approval of the Ethics Committee in our university.

Consent for publication

All authors read and approve the final manuscript.

\section{Declarations}

Competing interests

The authors declare that they have no competing interests.

\section{Funding}

The authors gratefully acknowledge Henan Medical Science and Technology Research Youth Project CoSponsored by the Province and Ministry in China No: SB201902020; Top Talent Fund of the Second Affiliated Hospital of Zhengzhou University, No. 2020BJRCA03; Henan Middle-Aged Youth Health Technology Innovation Talent Project No. YXKC2020059.

\section{Authors' contributions}

Shipeng Ning, Yang Zheng, Kun Qiao, Guozheng Li, Shouping Xu, Qian Bai: Analysis, Verification, Revision; Shouping Xu, Qian Bai: Conceptualization, Methodology, Analysis, Validation, Supervision; Writing

\section{Acknowledgements}

Not applicable.

\section{References}

1. Fang X, Cao J, Shen A. Advances in anti-breast cancer drugs and the application of nano-drug delivery systems in breast cancer therapy. Journal of Drug Delivery Science and Technology. 2020: 101662.

2. Sharifi M, Hasan A, Attar F, Taghizadeh A, Falahati M. Development of point-of-care nanobiosensors for breast cancers diagnosis. Talanta. 2020;217:121091.

3. Ma X, Wang Y, Liu X-L, Ma H, Li G, Li Y, et al. Fe 30 4-Pd Janus nanoparticles with amplified dualLoading [MathJax]/jax/output/CommonHTML/jax.js generation for breast cancer treatment. Nanoscale Horizons. 
2019;4:1450-9.

4. Khan S, Sharifi M, Bloukh SH, Edis Z, Siddique R, Falahati M. In vivo guiding inorganic nanozymes for biosensing and therapeutic potential in cancer, inflammation and microbial infections. Talanta. 2021;224:121805.

5. Choi WJ, Kim Y, Cha JH, Shin HJ, Chae EY, Yoon GY, et al. Correlation between magnetic resonance imaging and the level of tumor-infiltrating lymphocytes in patients with estrogen receptor-negative HER2-positive breast cancer. Acta Radiol. 2020;61:3-10.

6. Sharifi M, Jafari S, Hasan A, Paray BA, Gong G, Zheng Y, et al. Antimetastatic Activity of LactoferrinCoated Mesoporous Maghemite Nanoparticles in Breast Cancer Enabled by Combination Therapy. ACS Biomaterials Science Engineering. 2020;6:3574-84.

7. Hou H, Huang X, Wei G, Xu F, Wang Y, Zhou S. Fenton reaction-assisted photodynamic therapy for cancer with multifunctional magnetic nanoparticles. ACS Appl Mater Interfaces. 2019;11:29579-92.

8. Sharifi M, Hasan A, Nanakali NMQ, Salihi A, Qadir FA, Muhammad HA, et al. Combined chemomagnetic field-photothermal breast cancer therapy based on porous magnetite nanospheres. Sci Rep. 2020;10:5925.

9. Sharifi M, Hosseinali SH, Yousefvand P, Salihi A, Shekha MS, Aziz FM, et al. Gold nanozyme: Biosensing and therapeutic activities. Materials Science Engineering: C. 2020;108:110422.

10. Sharifi M, Hosseinali SH, Saboury AA, Szegezdi E, Falahati M. Involvement of planned cell death of necroptosis in cancer treatment by nanomaterials: Recent advances and future perspectives. Journal of controlled release. 2019;299:121-37.

11. Maharjan A, Dikshit PK, Gupta A, Kim BS. Catalytic activity of magnetic iron oxide nanoparticles for hydrogen peroxide decomposition: optimization and characterization. Journal of Chemical Technology \& Biotechnology; 2020.

12. Pal S, Jana NR. Pharmacologic Vitamin C-Based Cell Therapy via Iron Oxide Nanoparticle-Induced Intracellular Fenton Reaction. ACS Applied Nano Materials. 2020;3:1683-92.

13. He Y-J, Liu X-Y, Xing L, Wan X, Chang X, Jiang H-L. Fenton reaction-independent ferroptosis therapy via Glutathione and iron redox couple sequentially triggered lipid peroxide generator. Biomaterials. 2020: 119911.

14. Li M, Wang X, Lu S, He C, Wang C, Wang L, et al. Erastin triggers autophagic death of breast cancer cells by increasing intracellular iron levels. Oncology Letters. 2020;20:1-1.

15. Nakamura T, Naguro I, Ichijo H. Iron homeostasis and iron-regulated ROS in cell death, senescence and human diseases. Biochimica et Biophysica Acta (BBA)-General Subjects. 2019; 1863: 13981409.

16. Zhao M-X, Wen J-L, Wang L, Wang X-P, Chen T-S. Intracellular catalase activity instead of glutathione level dominates the resistance of cells to reactive oxygen species. Cell Stress Chaperones. 2019;24:609-19.

17. Zhang M-L, Wu H-T, Chen W-J, Xu Y, Ye Q-Q, Shen J-X, et al. Involvement of glutathione peroxidases in Loading [MathJax]/jax/output/CommonHTML/jax.js ast cancers. Journal of translational medicine. 2020;18:1-11. 
18. Yang L, Schoenfisch MH. Nitric oxide-releasing hyperbranched polyaminoglycosides for antibacterial therapy. ACS applied bio materials. 2018;1:1066-73.

19. Zhang Y, Tan S, Xu J, Wang T. Hydrogen therapy in cardiovascular and metabolic diseases: from bench to bedside. Cell Physiol Biochem. 2018;47:1-10.

20. Pearson-Smith JN, Patel M. Antioxidant drug therapy as a neuroprotective countermeasure of nerve agent toxicity. Neurobiol Dis. 2020;133:104457.

21. Zhang P, Li Y, Tang Y, Shen H, Li J, Yi Z, et al. Copper-Based Metal-Organic Framework as a Controllable Nitric Oxide-Releasing Vehicle for Enhanced Diabetic Wound Healing. ACS Appl Mater Interfaces. 2020;12:18319-31.

22. Li S, Liu R, Jiang $X$, Qiu Y, Song $X$, Huang G, et al. Near-infrared light-triggered sulfur dioxide gas therapy of cancer. ACS Nano. 2019;13:2103-13.

23. Khan S, Sharifi M, Hasan A, Attar F, Edis Z, Bai Q, et al. Magnetic nanocatalysts as multifunctional platforms in cancer therapy through the synthesis of anticancer drugs and facilitated Fenton reaction. Journal of Advanced Research. 2020.

24. Cao X, Ding L, Xie Z-z, Yang Y, Whiteman M, Moore PK, et al. A review of hydrogen sulfide synthesis, metabolism, and measurement: is modulation of hydrogen sulfide a novel therapeutic for cancer? Antioxid Redox Signal. 2019;31:1-38.

25. Li J, Li X, Yuan Y, Wang Q, Xie L, Dai Y, et al. Efficient Polysulfide-Based Nanotheranostics for TripleNegative Breast Cancer: Ratiometric Photoacoustics Monitored Tumor Microenvironment-Initiated H2S Therapy. Small. 2020;16:2002939.

26. He T, Qin X, Jiang C, Jiang D, Lei S, Lin J, et al. Tumor pH-responsive metastable-phase manganese sulfide nanotheranostics for traceable hydrogen sulfide gas therapy primed chemodynamic therapy. Theranostics. 2020;10:2453.

27. Corpas FJ, Barroso JB, González-Gordo S, Muñoz-Vargas MA, Palma JM. Hydrogen sulfide: A novel component in Arabidopsis peroxisomes which triggers catalase inhibition. Journal of integrative plant biology. 2019;61:871-83.

28. Wei T, Xiaojun X, Peilong C. Magnoflorine improves sensitivity to doxorubicin (DOX) of breast cancer cells via inducing apoptosis and autophagy through AKT/mTOR and p38 signaling pathways. Biomed Pharmacother. 2020;121:109139.

29. Zhao Y, Alakhova DY, Zhao X, Band V, Batrakova EV, Kabanov AV. Eradication of cancer stem cells in triple negative breast cancer using doxorubicin/pluronic polymeric micelles. Nanomed Nanotechnol Biol Med. 2020;24:102124.

30. Xinyong C, Zhiyi Z, Lang H, Peng Y, Xiaocheng W, Ping Z, et al. The role of toll-like receptors in myocardial toxicity induced by doxorubicin. Immunology letters. 2020;217:56-64.

31. Zhang M, Asghar S, Tian C, Hu Z, Ping Q, Chen Z, et al. Lactoferrin/phenylboronic acid-functionalized hyaluronic acid nanogels loading doxorubicin hydrochloride for targeting glioma. Carbohydrate Polymers. 2020: 117194. 
32. Kondapi AK. Targeting cancer with lactoferrin nanoparticles: recent advances. Nanomedicine. 2020;15:2071-83.

33. Lin W-C, Huang C-C, Lin S-J, Li M-J, Chang Y, Lin Y-J, et al. In situ depot comprising phase-change materials that can sustainably release a gasotransmitter $\mathrm{H} 2 \mathrm{~S}$ to treat diabetic wounds. Biomaterials. 2017;145:1-8.

34. Zhang W, Shi Y, Chen Y, Yu S, Hao J, Luo J, et al. Enhanced antitumor efficacy by paclitaxel-loaded pluronic P123/F127 mixed micelles against non-small cell lung cancer based on passive tumor targeting and modulation of drug resistance. Eur J Pharm Biopharm. 2010;75:341-53.

35. Chizenga EP, Abrahamse H. Nanotechnology in Modern Photodynamic Therapy of Cancer: A Review of Cellular Resistance Patterns Affecting the Therapeutic Response. Pharmaceutics. 2020;12:632.

36. Sharifi M, Attar F, Saboury AA, Akhtari K, Hooshmand N, Hasan A, et al. Plasmonic gold nanoparticles: Optical manipulation, imaging, drug delivery and therapy. J Controlled Release. 2019;311-312:170-89.

37. Sun M, Duan Y, Ma Y, Zhang Q. Cancer Cell-Erythrocyte Hybrid Membrane Coated Gold Nanocages for Near Infrared Light-Activated Photothermal/Radio/Chemotherapy of Breast Cancer. Int J Nanomed. 2020;15:6749.

38. Sathiyaraj E, Thirumaran S. Structural, morphological and optical properties of iron sulfide, cobalt sulfide, copper sulfide, zinc sulfide and copper-iron sulfide nanoparticles synthesized from single source precursors. Chem Phys Lett. 2020;739:136972.

39. Yang W, Xiang C, Xu Y, Chen S, Zeng W, Liu K, et al. Albumin-constrained large-scale synthesis of renal clearable ferrous sulfide quantum dots for T1-Weighted MR imaging and phototheranostics of tumors. Biomaterials. 2020;255:120186.

40. Shankaranarayanan JS, Kanwar JR, Abd AL-Juhaishi AJ, Kanwar RK. Doxorubicin conjugated to immunomodulatory anticancer lactoferrin displays improved cytotoxicity overcoming prostate cancer chemo resistance and inhibits tumour development in TRAMP mice. Scientific reports. 2016;6:1-16.

41. Zhang Y, Wang F, Liu C, Wang Z, Kang L, Huang Y, et al. Nanozyme Decorated Metal-Organic Frameworks for Enhanced Photodynamic Therapy. ACS Nano. 2018;12:651-61.

42. Falahati M, Attar F, Sharifi M, Saboury AA, Salihi A, Aziz FM, et al. Gold nanomaterials as key suppliers in biological and chemical sensing, catalysis, and medicine. Biochimica et Biophysica Acta (BBA)-General Subjects. 2019; 1864: 129435.

43. Zhang C, Bu W, Ni D, Zhang S, Li Q, Yao Z, et al. Synthesis of Iron Nanometallic Glasses and Their Application in Cancer Therapy by a Localized Fenton Reaction. Angew Chem Int Ed. 2016;55:21016.

44. He J, Zhang Y, Zhang X, Huang Y. Highly efficient Fenton and enzyme-mimetic activities of NH2-MIL88B(Fe) metal organic framework for methylene blue degradation. Sci Rep. 2018;8:5159.

45. Xie C, Cen D, Ren Z, Wang Y, Wu Y, Li X, et al. FeS@ BSA Nanoclusters to Enable H2S-Amplified ROSLoading [MathJax]/jax/output/CommonHTML/jax.js anced Science. 2020;7:1903512. 
46. Maji SK, Dutta AK, Biswas P, Srivastava DN, Paul P, Mondal A, et al. Synthesis and characterization of FeS nanoparticles obtained from a dithiocarboxylate precursor complex and their photocatalytic, electrocatalytic and biomimic peroxidase behavior. Appl Catal A. 2012;419:170-7.

47. Chen W, Li S, Wang J, Sun K, Si Y. Metal and metal-oxide nanozymes: bioenzymatic characteristics, catalytic mechanism, and eco-environmental applications. Nanoscale. 2019;11:15783-93.

48. Fu S, Wang S, Zhang X, Qi A, Liu Z, Yu X, et al. Structural effect of Fe304 nanoparticles on peroxidase-like activity for cancer therapy. Colloids Surf B. 2017;154:239-45.

49. Ma Y, Li X, Li A, Yang P, Zhang C, Tang B. H2S-Activable MOF Nanoparticle Photosensitizer for Effective Photodynamic Therapy against Cancer with Controllable Singlet-Oxygen Release. Angew Chem. 2017;129:13940-4.

50. Kou Z, Zhao P, Wang Z, Jin Z, Chen L, Su B-L, et al. Acid-responsive H2-releasing Fe nanoparticles for safe and effective cancer therapy. Journal of Materials Chemistry B. 2019;7:2759-65.

51. Singh N, Nayak J, Sahoo SK, Kumar R. Glutathione conjugated superparamagnetic Fe304-Au core shell nanoparticles for $\mathrm{pH}$ controlled release of DOX. Materials Science Engineering: C. 2019;100:453-65.

52. Xiao S, Lu Y, Feng M, Dong M, Cao Z, Zhang X, et al. Multifunctional FeS2 theranostic nanoparticles for photothermal-enhanced chemodynamic/photodynamic cancer therapy and photoacoustic imaging. Chemical Engineering Journal. 2020: 125294.

53. Xiao AY, Maynard MR, Piett CG, Nagel ZD, Alexander JS, Kevil CG, et al. Sodium sulfide selectively induces oxidative stress, DNA damage, and mitochondrial dysfunction and radiosensitizes glioblastoma (GBM) cells. Redox Biology. 2019;26:101220.

54. Shaikh S, Younis M, Rehman Fu, Jiang H, Wang X. Specific Oxide Nanoclusters Enhance Intracellular Reactive Oxygen Species for Cancer-Targeted Therapy. Langmuir. 2020;36:9472-80.

55. Wan X, Song L, Pan W, Zhong H, Li N, Tang B. Tumor-Targeted Cascade Nanoreactor Based on Metal-Organic Frameworks for Synergistic Ferroptosis-Starvation Anticancer Therapy. ACS Nano. 2020;14:11017-28.

56. Chang Y, Cheng Y, Feng Y, Jian H, Wang L, Ma X, et al. Resonance Energy Transfer-Promoted Photothermal and Photodynamic Performance of Gold-Copper Sulfide Yolk-Shell Nanoparticles for Chemophototherapy of Cancer. Nano Lett. 2018;18:886-97.

57. She D, Peng S, Liu L, Huang H, Zheng Y, Lu Y, et al. Biomimic FeS2 nanodrug with hypothermal photothermal effect by clinical approved NIR-II light for augmented chemodynamic therapy. Chem Eng J. 2020;400:125933.

58. Zou Y, Li D, Wang Y, Ouyang Z, Peng Y, Tomás H, et al. Polyethylenimine Nanogels Incorporated with Ultrasmall Iron Oxide Nanoparticles and Doxorubicin for MR Imaging-Guided Chemotherapy of Tumors. Bioconjug Chem. 2020;31:907-15.

59. Singh N, Millot N, Maurizi L, Lizard G, Kumar R. Taurine-conjugated mussel-inspired iron oxide nanoparticles with an elongated shape for effective delivery of doxorubicin into the tumor cells. ACS 
60. Popescu R, Savu D, Dorobantu I, Vasile B, Hosser H, Boldeiu A, et al. Efficient uptake and retention of iron oxide-based nanoparticles in HeLa cells leads to an effective intracellular delivery of doxorubicin. Scientific reports. 2020;10:1-10.

61. Fang C, Cen D, Wang Y, Wu Y, Cai X, Li X, et al. ZnS@ ZIF-8 core-shell nanoparticles incorporated with ICG and TPZ to enable H2S-amplified synergistic therapy. Theranostics. 2020;10:7671.

62. Tang X-I, Jing F, Lin B-I, Cui S, Yu R-t, Shen X-. pH-Responsive Magnetic Mesoporous Silica-Based Nanoplatform for Synergistic Photodynamic Therapy/Chemotherapy. ACS Appl Mater Interfaces. 2018;10:15001-11. d et al.

63. Wang D, Li X, Li X, Kang A, Sun L, Sun M, et al. Magnetic And pH Dual-Responsive Nanoparticles For Synergistic Drug-Resistant Breast Cancer Chemo/Photodynamic Therapy. Int J Nanomed. 2019;14:7665.

64. Luo X, Zhang J, Wu Y-P, Yang X, Kuang X-P, Li W-X, et al. Multifunctional HNT@Fe304@PPy@DOX Nanoplatform for Effective Chemo-Photothermal Combination Therapy of Breast Cancer with MR Imaging. ACS Biomaterials Science Engineering. 2020;6:3361-74.

\section{Figures}



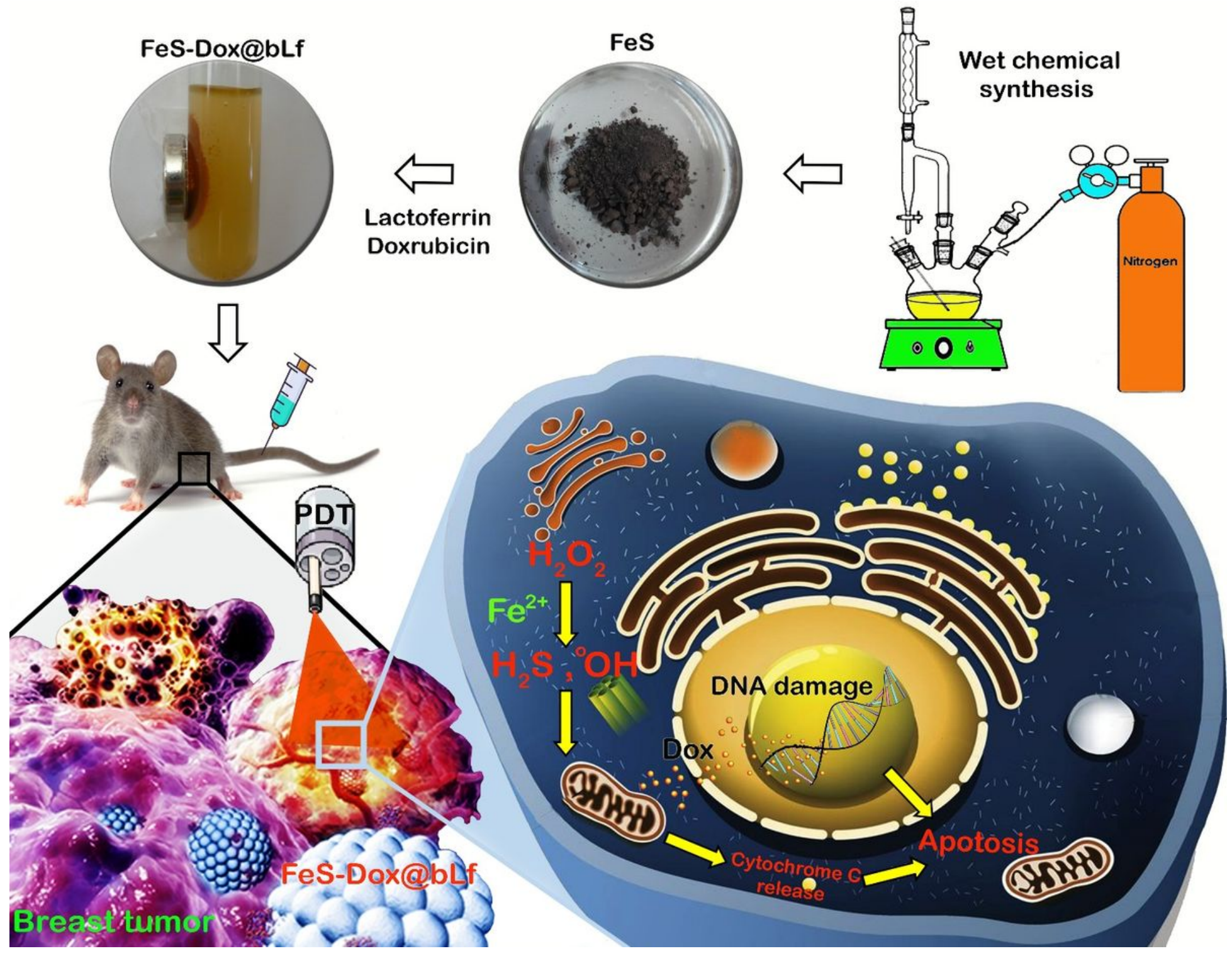

Figure 1

Graphical representation of the fabrication of FeS-Dox@bLf NZs and effect on breast cancer therapy with chemo and photodynamic combination therapy. 

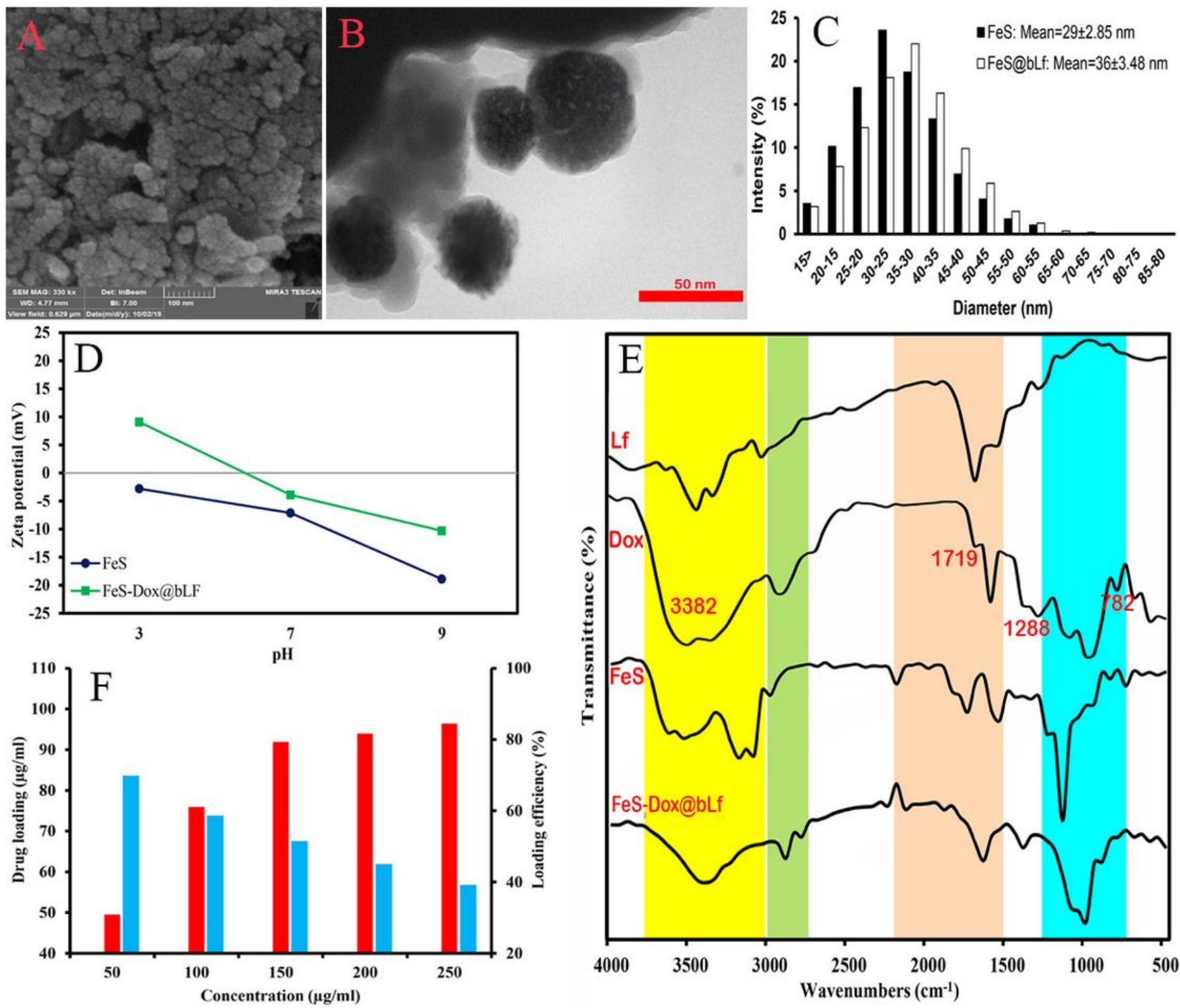

Figure 2

FE-SEM (A) and TEM (B) images of FeS-Dox@bLf, (C) FeS and FeS-Dox@bLf sizes distribution determined by DLS, (D) Dependence of the zeta potential $\zeta$ on the pH of the solution, (E) FTIR spectra of bLf, Doxo, FeS and their conjugates, $(F)$ drug loading and its efficiency. 

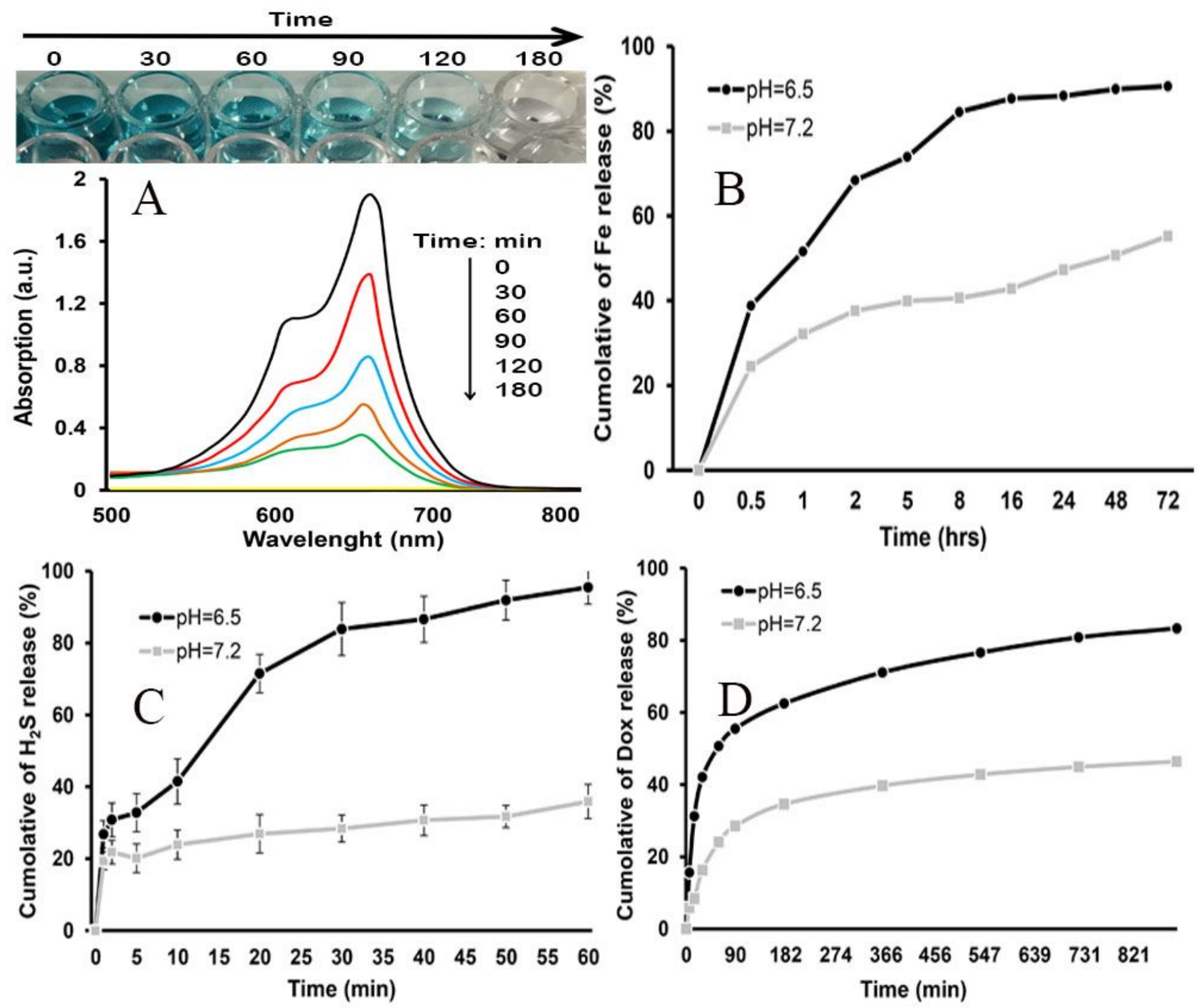

Figure 3

(A) Photographs of solutions and time dependent absorbance spectral change of aqueous solution of methylene blue catalyzed by 20 mg FeS-Dox@bLf NZs adding to H2O2 (9 mM)/NaHCO3 (25 mM) solution under light irradiation for 180 min, (B) Levels of Fe+ released from FeS-Dox@bLf in PBS buffer of pH 6.5 and 7.2. (C) Levels of H2S gas released from FeS-Dox@bLf NZs at HEPES buffer of pH 6.5 and 7.2, and (D) Quantitative analyses of Dox release at $37^{\circ} \mathrm{C}$ from FeS-Dox@bLf NZs at pH 6.5, and 7.2. 

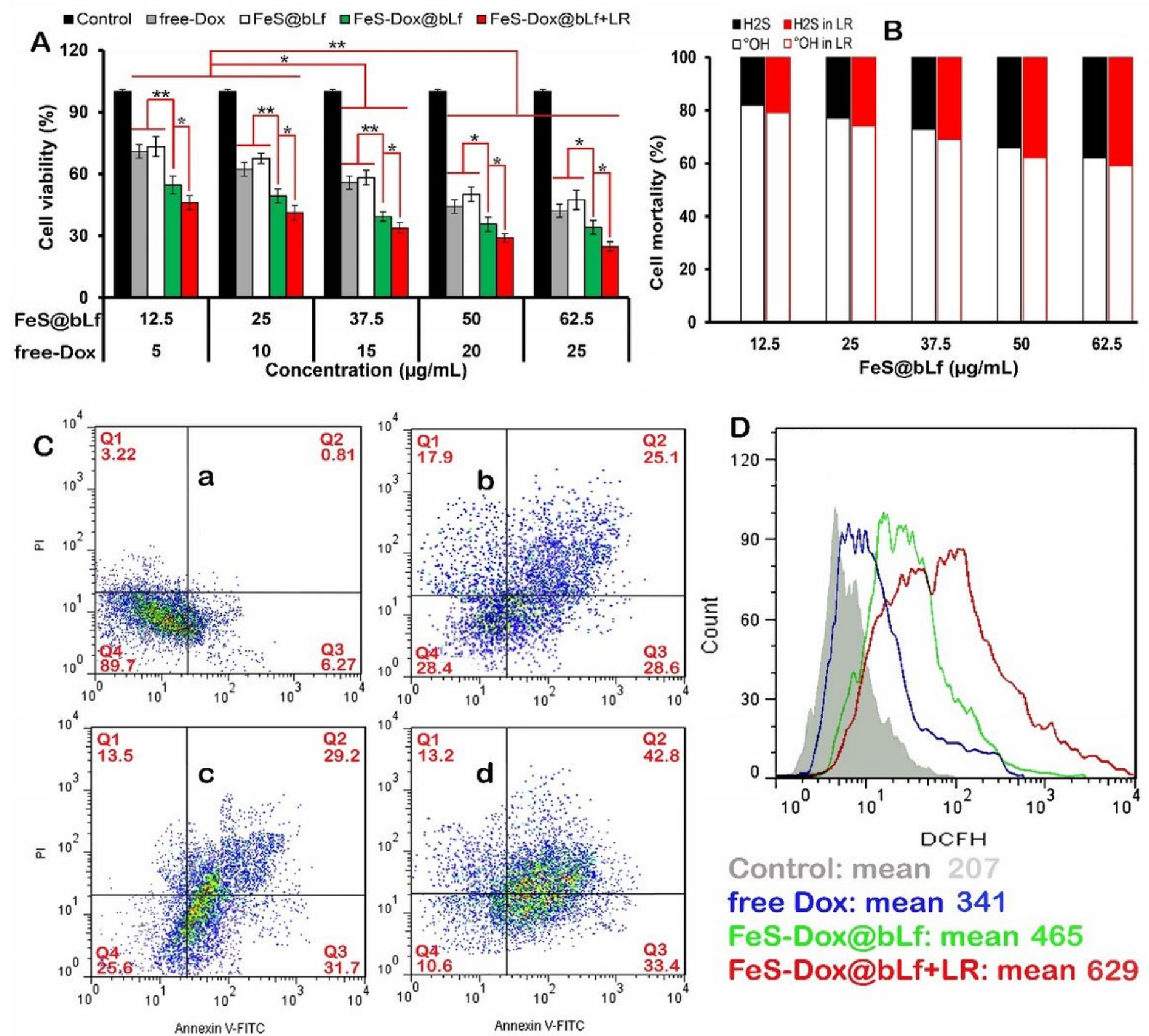

Control: mean 207

free Dox: mean 341

FeS-Dox@bLf: mean 465

FeS-Dox@bLf+LR: mean 629

Figure 4

(A) Cytotoxicity test of free Dox, FeS NZs, and FeS-Dox@bLf NZs with or without laser irradiation (LR), on $4 T 1$ cells by MTT assay, (B) Mortality of $4 \mathrm{~T} 1$ cancerous cells triggered by $\cdot 0 \mathrm{H}$ radicals and $\mathrm{H} 2 \mathrm{~S}$ gas after treated with FeS@bLf with or without laser irradiation (LR) for $24 \mathrm{~h}$, (C) Two-dimensional contour density plots of 4T1 cells obtained by flow cytometry-based assays. a: Control, b: free Dox, c: FeS-Dox@bLf NZs, and d: FeS-Dox@bLf NZs+LR. Cell necrosis and apoptosis were measured using propidium iodide (PI) and Annexin V-FITCH dyes, (D) The effects of a: Control, free Dox, FeS-Dox@bLf NZs, and FeS-Dox@bLf NZs+LR NZs on the ROS production. Statistical differences were measured at level of $* P<0.05$, and **P<0.01. 

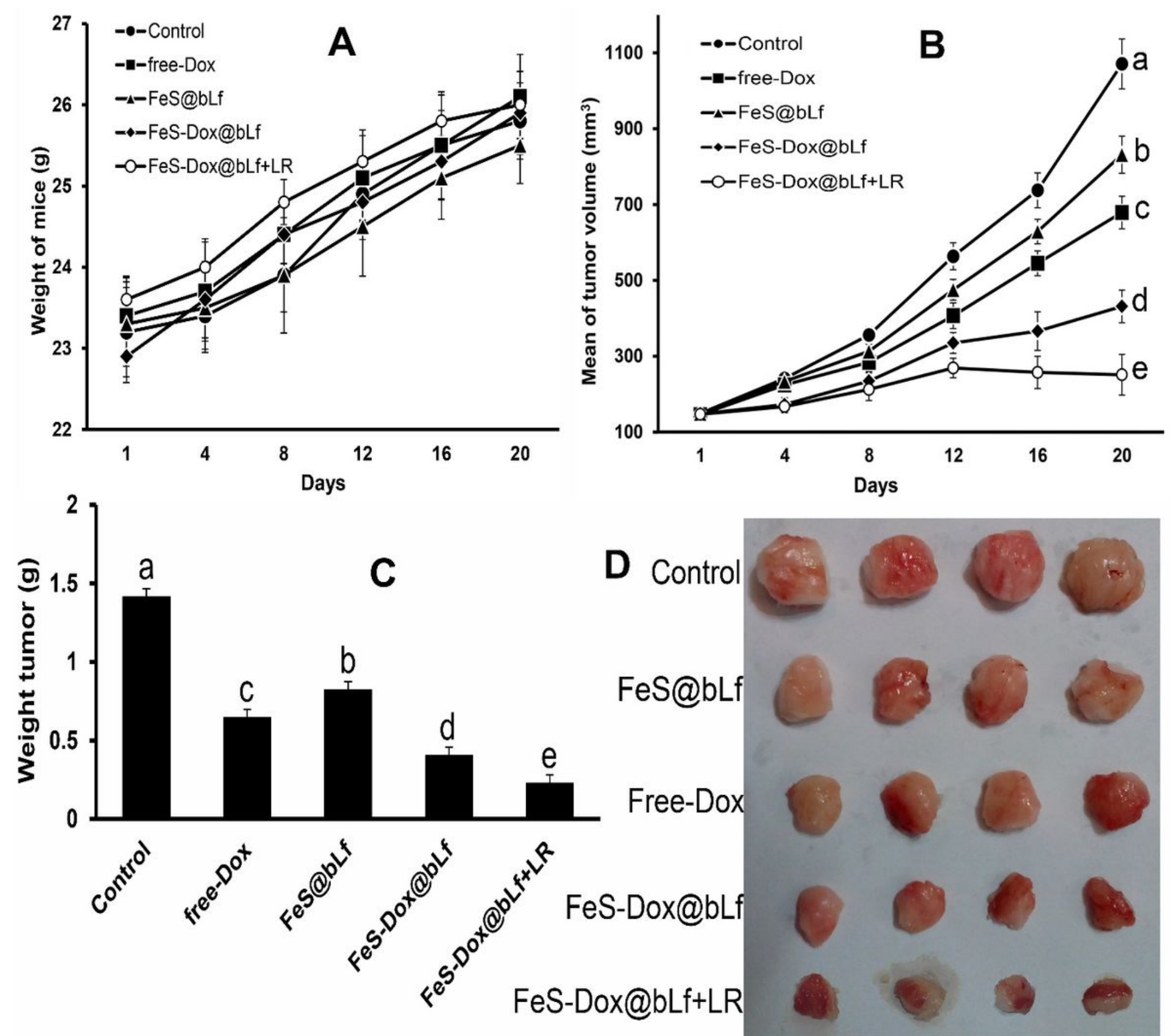

Figure 5

(A) Body weight change of mice, (B) Tumor volume curves of different groups after treatment, (C) Mean weight, and (D) digital photographs of tumor on day 20. a,b,c,d,eLS means with different letters in superscripts are different at $* P<0.05$. 

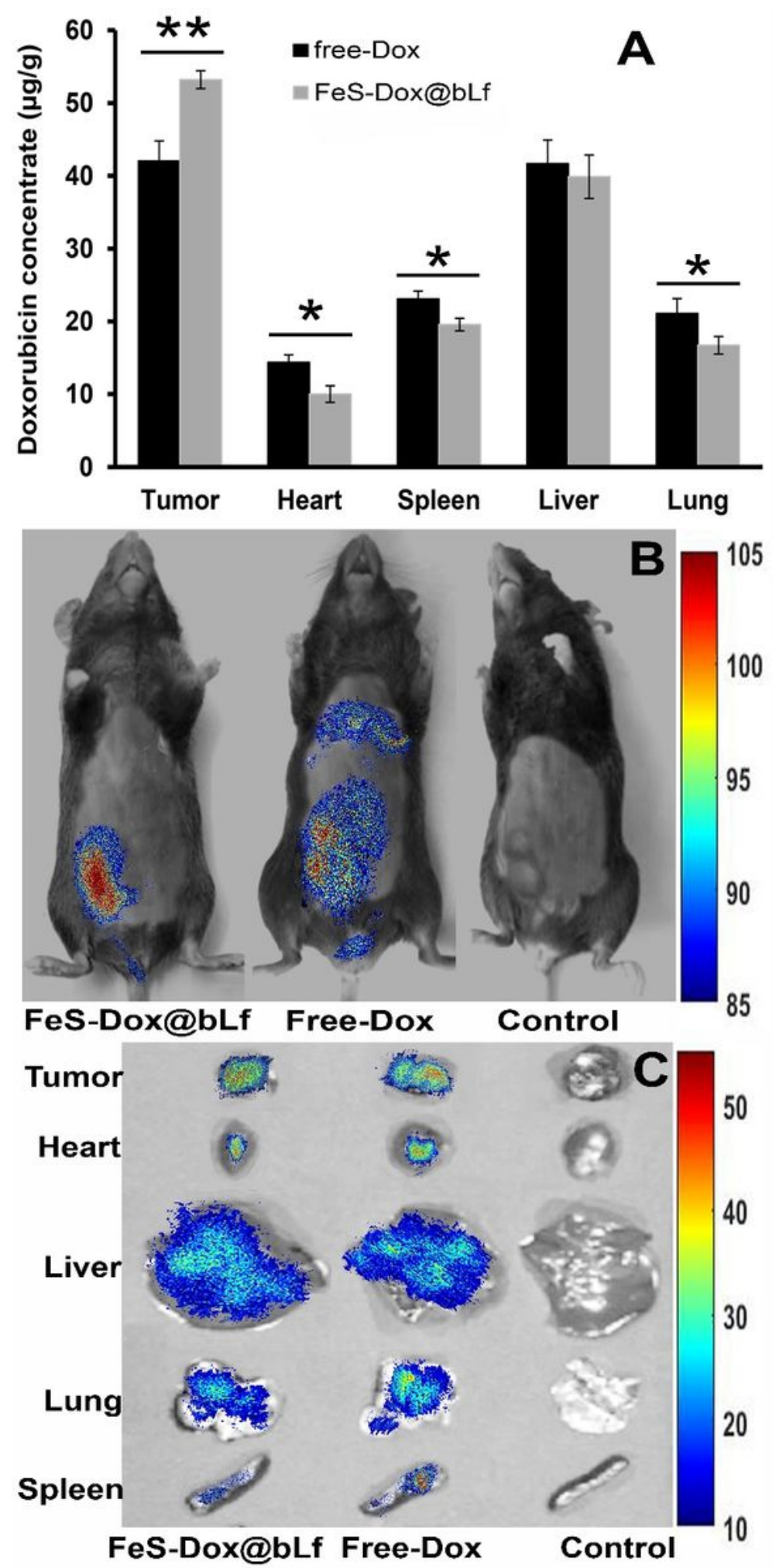

Figure 6

(A) Concentration of Dox in tumor and major organs, (B) Biological distribution of Dox in whole body, and (C) Major organs in mice by fluorescence imaging, $8 \mathrm{~h}$ after they were i.v. injected with free Dox, and FeSDox@bLf NZs. Statistical differences were measured at level of * $P<0.05$, and ** $P<0.01$. 

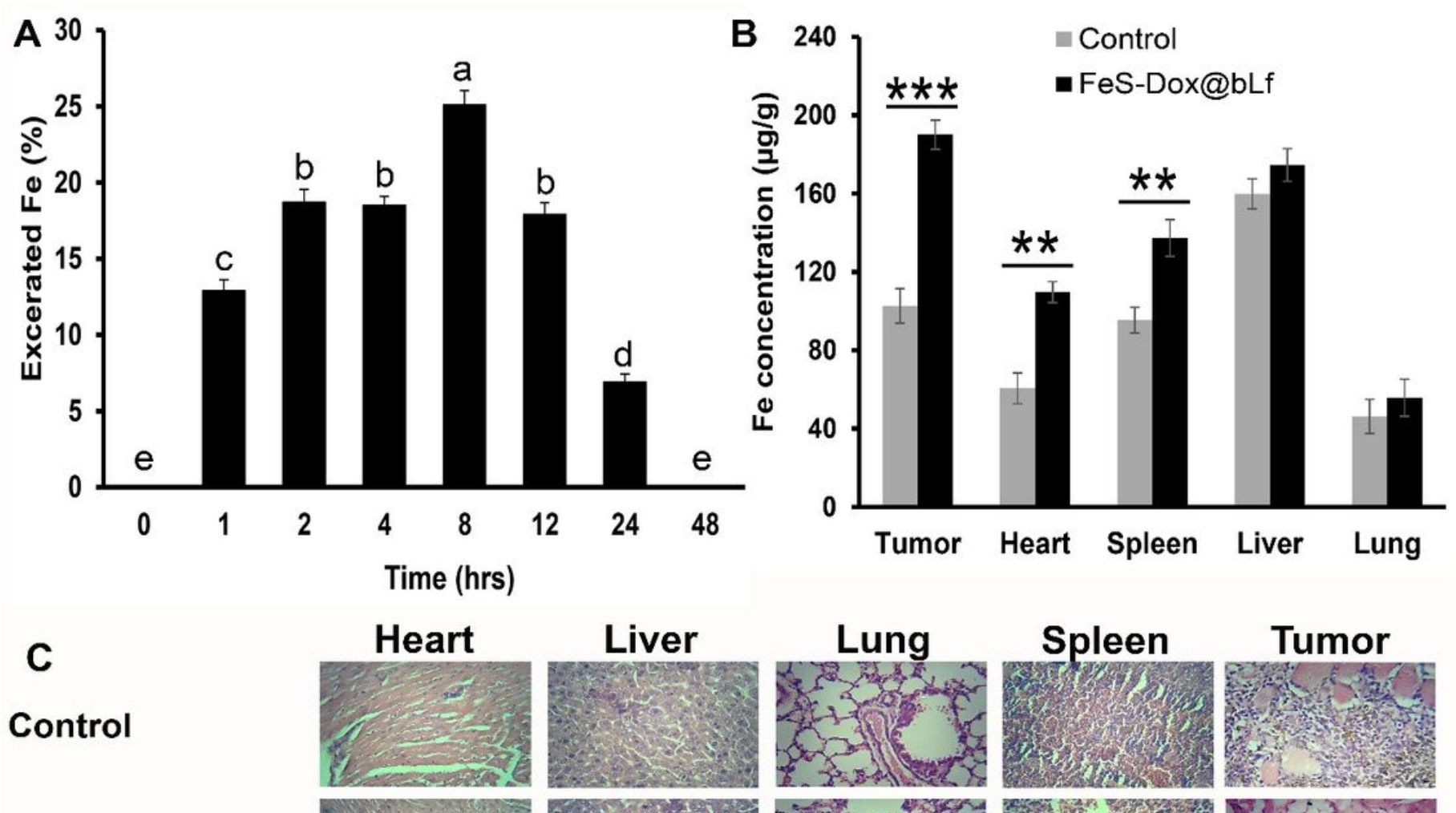

Free Dox

FeS-Dox@bLf

FeS-Dox@bLf+LR
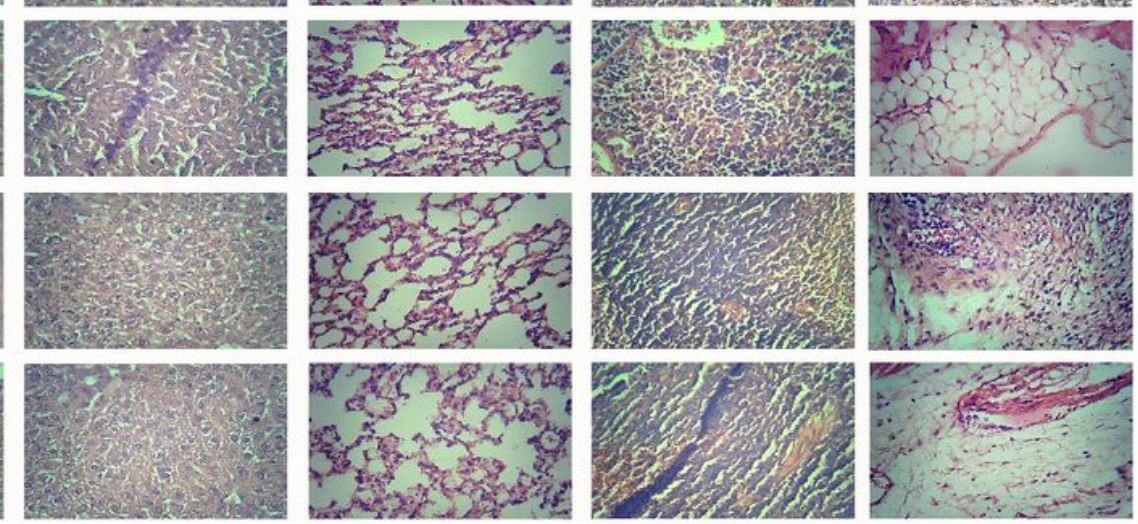

Figure 7

(A) The content of Fe element in mice urine and faces after injection of FeS-Dox@bLf, (B) Biological distribution of $\mathrm{Fe}$ in major organs, and (C) Histological observation of treated breast tumor tissues and major organs include of heart, lung, liver and spleen visualized using H\&E staining. a,b,c,d,eLS means with different letters in superscripts are different at $* P<0.05$. Statistical differences were measured at level of $* * P<0.01$, and $* * * P<0.001$.

\section{Supplementary Files}

This is a list of supplementary files associated with this preprint. Click to download.

- GraphicalAbstract.docx 